\title{
Analysing Union Power, Opportunity and Strategic Capability: Global and Local Union Struggles Against the General Agreement on Trade in Services (GATS)
}

\author{
Donna McGuire, University of Kassel, Germany
}

\begin{abstract}
This article presents a framework for identifying opportunities, and assessing the power and capacity needed for unions to develop strategic campaigns that can effectively challenge current neoliberal policy and practice (e.g. financialisation, trade liberalisation, privatisation and precarisation of labour). As the following analysis of union protests against the General Agreement on Trade in Services (GATS) shows, opportunities to oppose and challenge the current system do exist but these opportunities must be recognised and strategically framed in a way that encourages widespread contestation and solidarity. In addition, oppositional movements must prioritise the issue and have sufficient power, and mobilisation and organisational capacity, to take advantage of opportunities where they are identified. I argue that this framework, which draws on social movement theory concepts and studies on the sources of union power, provides conceptual tools that can be utilised for analytical assessment of past union campaigns and further developed for improving campaign planning.
\end{abstract}

\section{KEY WORDS}

campaigns, GATS, power, social movement theory, unions

\section{Introduction}

The labour movement along with other social movements is faced with the urgent need to build a counter movement to the prevailing system of transnational domination, often referred to as 'neoliberal globalisation' (Evans 2005). This system has promoted market liberalisation, privatisation, financialisation and, more recently, austerity policies that threaten livelihoods and the environment, and undermine basic social services and food security.

While unions face considerable constraints such as declining power and lack of resources, ${ }^{1}$ the current terrain of neo-liberal globalisation also provides avenues for contestation (Tarrow 2005, Evans 2005). The World Trade Organisation (WTO), for example, provides an institutionalised site of power and struggle and acts as a major condensing symbol for grievances (Tarrow 2005). 
Taking union protests against the WTO's General Agreement on Trade in Services (GATS) as a case study, the research presented in this article shows that even where unions face considerable constraints they can utilise such avenues to build resistance to neoliberal policies.

The GATS negotiations are particularly important because they have become something of a symbolic issue for broader discontent with neoliberal policies and the encroachment of external trade rules into more and more aspects of daily life (Jawara and Kwa 2003). The international union movement, along with other civil society groups and movements, has seen the development of the GATS as a threat to the domestic regulation and provision of public and essential services (Hartmann and Scherrer 2003). In many countries these services have already been under threat from neoliberal policies that encourage deregulation and privatisations (Hall 2001). Unions have argued that trade liberalisation is likely to exacerbate this situation (Hartmann and Scherrer 2003). As a result, unions at the global and national level have been part of a 'counter-movement' (in the sense used by Polanyi, 1944) against the GATS, and the institution and policies underpinning it. $^{2}$

At the international level, the union movement is organised in two distinct but interacting networks: national federations of unions are affiliated to the International Trade Union Confederation (ITUC), while national sectoral unions are affiliated to their respective global union federations (GUFs). Due to the perceived threat to public services and education, the research focused predominantly on the global and local struggles of Public Services International (PSI) and Education International (EI), which are the two GUFs representing the interests of unions (and their members) in these sectors. ${ }^{3}$ Both PSI and EI also have a long history of advocacy in relation to preserving and extending access to public services and education. The time period analysed was from the 1999 WTO Ministerial meeting in Seattle to the breakdown and temporary suspension of the GATS negotiations in 2006, as this was the period of most intense action.

A comparative dimension (between levels and countries) was added to the research by analysing union responses to the GATS in Australia and South Africa. This included key PSI and EI affiliate unions and the national union federations. Australia and South Africa were chosen because they share a range of similarities but with some key differences. Both countries are WTO members, with interests in gaining new market access in the trade in services, and in both countries successive governments have adopted a broad range of neo-liberal strategies, including trade liberalisation and privatisation of public services. On the other hand, Australia is an OECD country with a declining labour movement characterised by a relatively narrow focus on the interests and social protections of workers and their families, while South Africa is a developing country with a strong union movement, characterised by a broad social movement form of unionism that focuses on workers' interests as part of wider social issues (McGuire 2013: 10-12). This multi-level comparative approach was designed to capture the interaction between the various scales of mobilisation (global/national) and the influence of national context, institutional arrangements and union dynamics on union mobilisation.

In the following section I explain the conceptual framework and indicators developed to analyse the union struggles against the GATS and the methodology used to obtain the empirical data. I then describe the empirical findings through the 'lens' of this theoretical framework. This is followed by an assessment of the impact of union action and discussion of findings. Finally, I assess the robustness of the theoretical framework and discuss its potential future applications to union research and practice. 


\section{A Framework for Assessing Opportunities, Capacity and Power}

Counter movements, such as the broad civil society and union mobilisation against the GATS, cannot be understood simply as some kind of spontaneous or reflexive response to the negative impact of trade agreements on workers' lives (Munck 2002; Webster, Lambert and Bezuidenhout 2008). Such mobilisation is part of a process that requires resources, capacity and the development of collective power (McAdam 1996, Tarrow 2005). Nor does such mobilisation develop independently from the social, institutional, political, and economic context within which unions are embedded (Hyman 2001). This context shapes the structural and political opportunities available to them both generally, and more specifically within the particular terrain and issue field in which they are addressing their claims. Therefore, to understand trade union mobilisation against the GATS one needs a way to analyse the context in which this mobilisation developed and the resources and capabilities that union movements had available to them, including the sources of power that unions were able to draw on to take action.

I argue that this can be achieved by using three core concepts derived from social movement theory (SMT): political opportunity structure (POS); mobilisation and organisational capacity (MOC); and framing. Here I draw mainly on work by McAdam (1982), McAdam, McCarthy and Zald (1996), Tarrow (1998 and 2005), Benford and Snow (2000) and Meyer (2004). ${ }^{4}$ While these concepts were initially developed to explain the success or failure of social movement action in relation to national political systems, they are equally valuable for explaining the success or failure of labour movement mobilisation, at both the national and international levels.

An analysis of the political opportunity structure impacting on a movement (in this case the labour movement) can focus attention on the 'contextual' factors 'which facilitate or limit the building of a specific movement structure, resource collection, and the eventual carrying out of protest activities' (Rucht 1996: 188).

A resource mobilisation approach can shed light on the 'internal' factors impacting on union mobilisation. Resource mobilisation theory recognises that far from being irrational, spontaneous or disorganised, social movements are the product of rational choice by individuals to join a movement, and deliberate action by social movement organisations to obtain and mobilise resources in a way that encourages collective action (McCarthy and Zald 1987). Such an approach can help address the questions of what resources are available to a movement and how they are organised and mobilised. It can therefore help explain why similar 'objective' structural conditions (POS) may generate stronger or weaker mobilisation capacities (Frundt 2005: 26).

However, both political opportunity structure and resource mobilisation theory neglect the important role of collective identity formation in mobilisation (Rucht 1996) and fail to capture the ideational, social and cultural contexts, which facilitate or restrain collective action. Such contexts are best captured through a more discursive approach such as framing (Benford and Snow 2000). A framing approach also recognises that 'the struggle over the production of mobilising and counter mobilising ideas and meanings' (Benford and Snow 2000: 613) is a power struggle, and that movements and movement actors are active participants in this process.

The following section expands on these key theoretical concepts and the indicators developed to analyse them. 


\section{POLITICAL OPPORTUNITY STRUCTURE (POS)}

POS refers to the 'openness' of a system or organization to external demands, whether through social movements or trade unions (Meyer 2004, Sikkink 2005). It includes the government's propensity for exclusion and repression and its vulnerability to social protest (McAdam et al. 1996: 28, Tilly 1978). POS is not static (Tarrow 2005, Sikkink 2005). It can vary, depending on the issue, the policy field, the country context, and the time frame in which action takes place. To map POS one must look at the specific structures of the political system and issue field to be influenced. Important factors for influencing trade policy appear to include:

a) Who controls the trade policy process;

b) The formal and informal mechanisms and procedures for labour and/or civil society inclusion and participation that exist;

c) Policy legacy, receptivity and consensus within relevant ministries and government departments; and,

d) The willingness of the state to repress mobilisation, versus its vulnerability to protest (McGuire and Scherrer et al. 2010).

\section{SITUATIONAL OPPORTUNITIES}

Beyond these more general factors of political opportunity structure, 'windows of opportunity' such as elections or key junctures in the policy process can provide 'situational opportunities' (McGuire and Scherrer et al. 2010) for union intervention, as it may be easier to raise the level of media attention and public debate during these times, and governments are likely to be more responsive and/or sensitive to criticism (McCarthy, Smith and Zald 1996).

\section{MOBILISATION AND ORGANISATIONAL CAPACITY (MOC)}

To take advantage of openings in the political process, movements must be willing and able to provide sufficient resources for collective action (McAdam et al. 1996, Rucht 1996), including tangible factors such as staff, facilities, money and means of communication and intangible factors such as skills and expertise (Rucht 1996). The mobilisation of these resources requires effective mobilisation structures and organisational capacity (McAdam et al. 1996, Rucht 1996).

For union movements, mobilisation structures include its formal affiliate and delegate structures, engaged membership and external and non-union networks and alliances. While organisational capacity is not easy to define, it can be understood as the capability of unions to assess opportunities for intervention, develop coherent policies and strategies and effectively organise and mobilise resources so as to achieve desired outcomes (Hyer 2007: 198). I group these factors together as mobilisation and organisational capacity (MOC). ${ }^{5}$ Beyond making the issue a priority, important factors for MOC appear to be:

a) The unity and coherence of the union movement, as this affects its collective strength and capacity to mobilise members behind a common position (Hyman 2007, Robinson 1994); 
b) The effectiveness of a union movement's mobilisation and organisational structures. This includes its affiliate and delegate structures, union networks, and external alliances and coalitions, and its capability for strategic planning and organisation and mobilisation of resources to achieve desired outcomes.

c) Sufficient specialist knowledge and expertise, as these capabilities are necessary for understanding the impact of issues on members and where to intervene in the policy process, and for framing and legitimising claims (Hyman 2007, McGuire and Scherrer et al. 2010).

\section{FRAMING CAPABILITIES}

Having opportunity and capacity is not sufficient. Successful mobilisation requires a consensus or set of common beliefs about the general or specific issue, i.e. shared value orientations, problem descriptions and solutions, and a willingness to take action. Where these do not exist, they must first be created. This can be done by framing specific problems in a way that resonates with constituents (e.g. union members), alliance partners and the general public. To do this movements frequently draw on existing sets of interpretive ideas about what is considered an injustice or violation of rights (Rucht 1996).

The main tasks of framing is to:

a) Identify an issue as a problem and assign blame (diagnostic frames);

b) Suggest solutions and strategies to deal with the problem (prognostic frames); and,

c) Provide a rationale for taking action (mobilising frames) (Bedford and Snow 2000: 614).

Both diagnostic and prognostic frames encourage the development of consensus about the problem and proposed solutions, while mobilising, or motivational frames provide compelling reasons for taking action (Benford and Snow 2000: 615). At the minimum, people need a shared sense of grievance and hope that they can somehow redress the problem (McAdam et al. 1996: 5).

Such frames are not static, but evolve and change over the course of a campaign to retain interest and respond to new developments (McCarthy 1996). In addition, movement frames are subject to contestation and redefinition by oppositional and interested bodies, such as the mass media. Therefore the movement 'story' must be in a constant process of framing and re-framing (Zald 1996: 261-262).

\section{POWER DIMENSION - A TYPOLOGY OF UNION POWER}

The social basis for collective action stems from a contention for power between those who hold it in society and challengers who are excluded (Tilly 1978). As social movement theory does not provide sufficient conceptual tools for understanding where the labour movement draws its power for political action, I add a power dimension, which draws on existing insights from labour research including:

- Old and new forms of associational and structural power, often seen as the traditional forms of union power (Silver 2003); 
- Newly identified forms of logistical and symbolic power (Webster, Lambert and Bezuidenhout 2008; Chun, 2005 and 2009);

- Institutional power, an overlooked dimension of union power (Dörre, Holst and Nachtwey 2009); and,

- Networking and coalition building, seen as important for boosting union power (Frege et al. 2004, Turner 2006, Tattersall, 2010).

To this I add discursive power, which I argue is necessary to capture the more hidden ideological dimensions of power that enable and constrain action and agendas (Hajer, 1995 and 2006). Framing, as outlined above, is the key process through which discursive power is exercised through language. I categorise logistical power as a form of structural power exercised in the public domain (which often draws on 'symbolic' power for legitimation), and symbolic power as a form of discursive power. These forms and manifestations of power are captured in the fourfold typology of union power below (Diagram 1). However, these 'archetypal' forms of union power should not be seen as separate or competing but as interrelated and intertwined, rarely existing by themselves but combining in unexpected ways that can enhance or leverage each other.

\section{Diagram 1. Forms and manifestations of union power}

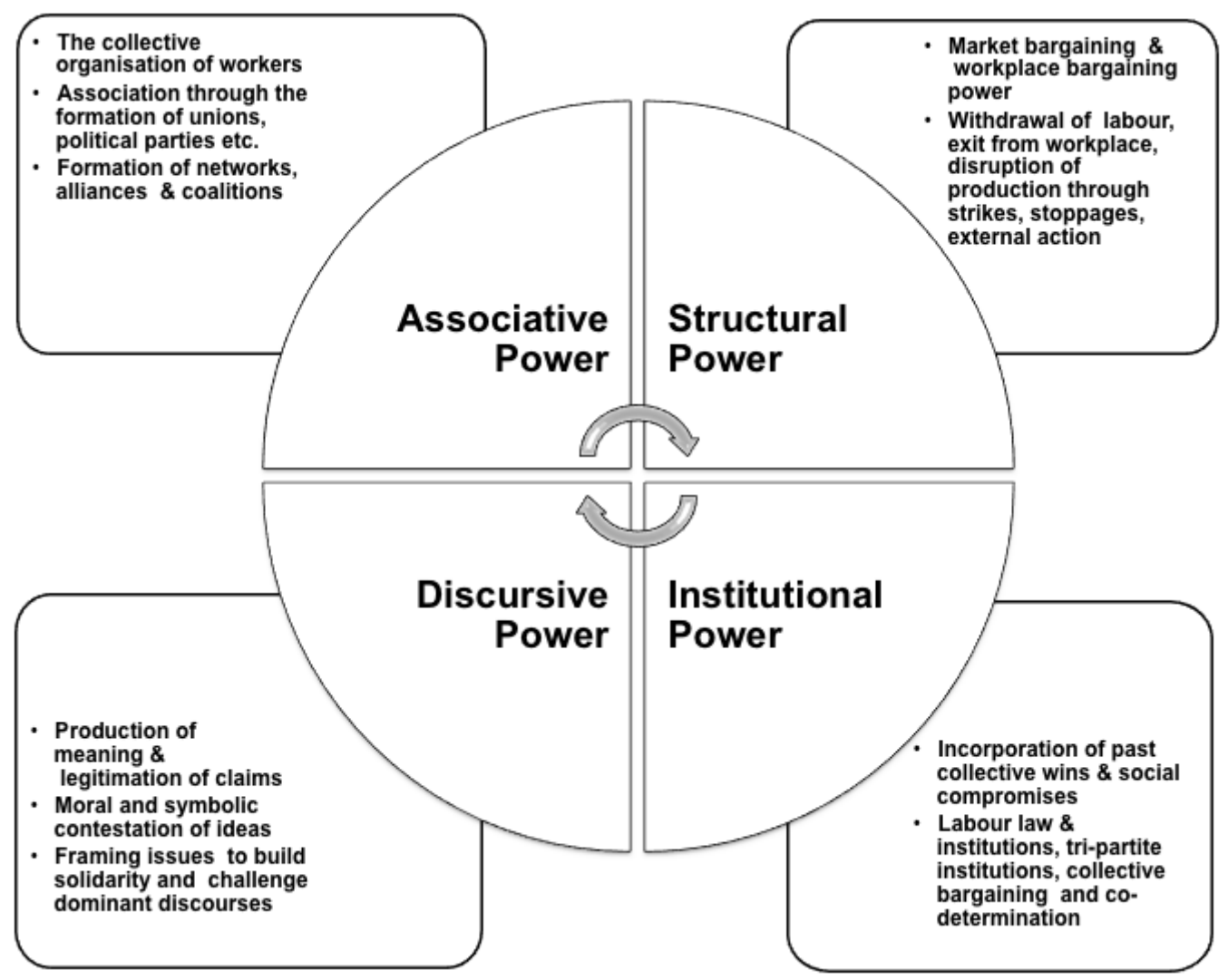

(C) Donna McGuire 2013

Drawn from Silver (2003), Chun (2005 and 2009), Webster et al. (2008) Dörre et al. (2009), Frege et al. (2004), Tattersall (2010), and Hajer (1995) 


\section{INTERACTION OF POWER, POS AND MOC}

In order to intervene in an economic or policy arena, unions draw on one or more forms of power (as outlined above). The form and extent of power available will be shaped by both the political opportunity structure (POS) in which unions are operating and their own mobilising and organisational (MOC) capacity. All of these factors will impact on the strategies, or 'repertoires of contention' (Tilly 1978) available to and utilised by unions to achieve their aims. The theoretical framework outlined above was used to analyse a case study of the global and local union struggles against the GATS.

\section{Methodological Strategies and Restrictions}

Between July 2005 and September 2011, I interviewed key union leaders and officials from PSI and EI, and their affiliated unions in Australia and South Africa, concentrating mainly on those who were responsible for trade issues and campaigning against the GATS. I started with a handful of key experts and other respondents were identified through 'snowball sampling'. Key union leaders/officials in the ITUC and the national union federations (Australia and South Africa) were also interviewed to ascertain their role in mobilising union action against the GATS. In addition, I interviewed trade activists from significant union/civil society coalitions and NGOs that were active against the GATS, and national-level trade bureaucrats and politicians. Questions were guided by the variables developed in the theoretical framework. ${ }^{6}$

The research findings rely heavily on a relatively small number of key 'experts'. This reflects the significant role they played in identifying the GATS as a threat, and mobilising support for action against it. Although most of them were senior union officials, they also acted as 'activists' in framing and disseminating issues and persuading their union organisations to take action against the GATS. It also reflects the fact that expertise about trade-related issues within the union movement (and civil society) is confined to a handful of people at relatively senior levels.

Another limitation is the lack of interviews with more 'grass-roots' activists and union members. I had planned to interview or survey union members from the key national unions to ascertain their level of awareness and engagement in campaign action. However, restrictions to time and resources, and the difficulty of identifying a meaningful sample, made this impractical. Here I had to rely on insights from union officials.

The other major source of information was from the campaign materials and the websites of the union and civil society organisations involved and secondary literature on the trade policy process and union context at the international level and in the case study countries.

\section{Global and Local Union Struggles Against the GATS}

\section{BACKGROUND}

Union mobilisation against the GATS needs to be seen in the context of existing and ongoing privatisation in the public sector in many countries (Hall 2001) and a growing interest in trade in services.

The General Agreement on Trade in Services (GATS) was established as part of the Uruguay Round of multilateral trade negotiations (1986-1994) that created the WTO in 1995 
(Kelsey 2008: Ch.2). Its inclusion in the WTO was driven largely by the U.S., with the support of powerful services lobby groups, think tanks and academic supporters (ibid). As part of the initial negotiations, WTO members committed themselves to the progressive liberalisation of services, including a new round of negotiations to begin by 2000 (Kelsey 2008: Ch.2). The GATS negotiations have since been incorporated into the Doha round of negotiations, which is on-going.

In theory, countries do not 'have to' liberalise any services under GATS but in practice they face considerable pressure to do so (Jawara and Kwa 2003, Kelsey 2008: Ch.2). Once such a decision is made countries face two levels of commitment. The first level commits them to the three central principles of the WTO: most-favoured nation (MFN), national treatment, and transparency. In effect, this means that trade concessions granted to one country must be granted to all WTO members (with some exceptions for regional trade blocs), that foreign service providers must be treated no less favourably than domestic providers, and that the WTO must be informed of any relevant changes to laws, regulations and administrative guidelines. The second level involves specific commitments in the service areas countries choose to liberalise (Scherrer 2002).

Proponents of the GATS have stressed the potential of trade in services to stimulate economic growth, particularly where traditional means of growth have slowed (Kelsey 2008, Hartmann and Scherrer 2003). However, critics, including trade unions, have argued that the framework of the GATS is more likely to intensify international trade and lead to the opening up of global markets to multinational services corporations, without any real benefits in terms of better employment or sustainable development (Hartmann and Scherrer 2003: 7). Unions argue that the potential of the GATS to escalate the liberalisation and privatisation of essential and other basic services will aggravate social disparities, and that WTO rules and disciplines will jeopardise the capacity of governments to regulate services and meet universal service provisions that guarantee equitable access. Assurances from the WTO that there are sufficient existing provisions within the GATS to protect public services have been rejected as untested and inadequate (Krajewski 2001). A large part of unions' political campaigning against the GATS has therefore focused on keeping, or getting public services, such as health, education and water, out of the GATS.

\section{MULTILEVEL SCALE OF POLITICAL OPPORTUNITY STRUCTURE}

The scale of union action in relation to the GATS took place at both the national and international levels. This is due to the nature of the multilateral trading system itself, as an organisation of national governments that meet internationally to negotiate agreed rules for international trade. While multilateral negotiations take place at the international level, at the WTO in Geneva, and at other international locations where WTO Ministerial meetings are held, decisions about trade policy and negotiating positions for WTO agreements (including the GATS) are formulated at the national level (WTO 2010).

This meant that unions were forced to operate at both levels in trying to influence the GATS negotiations: at the international level to influence trade delegates, Ambassadors and bureaucrats responsible for the day-to-day negotiations and at the national level to influence the major negotiating positions of governments. 


\section{POS, MOC AND POWER - INTERNATIONAL LEVEL}

At the international level PSI and EI faced a relatively closed political opportunity structure. Organised labour has no institutionalised access to the multilateral trade policy process at the international level and little informal access to decision makers. The WTO is neither a tripartite organisation, nor is it based on any concept of social partnership or social dialogue. In WTO terms, global union organisations and their affiliated unions are just like any other NGO or private sector interest group. There are some limited opportunities to participate in 'dialogue' processes and forums but on the whole WTO bureaucrats have been reluctant to recognise unions as legitimate stakeholders in the trade negotiation process.

PSI and EI also faced limitations to their mobilising and organisational capacity (MOC). Given the size of the international union network of which they are a part (Boswell 2008: Ch.3), PSI and EI had the potential capacity to mobilise considerable transnational solidarity and crossborder action in relation to the GATS. However, this capacity was limited by a number of constraints, including: lack of unity and solidarity in relation to priorities and strategies; limitations to affiliate and delegate structures and organisational capacity; restrictions to internal capacity and resources; and, the complex nature of the issues related to the GATS. These are elaborated below.

As identified in the theoretical framework, the degree of unity and coherence of the union movement affects its collective strength and capacity to mobilise members behind a common position (i.e. build solidarity). The international union movement is becoming more unified (Stevis and Boswell 2008) and the two sections of the international union movement, represented by the ITUC and the GUFs, cooperate quite strongly (Fairbrother and Hammer 2005). Nonetheless, there are disagreements over priorities and strategies both at the international crossborder and national level. This prevents the international union organisations from working more effectively together. At the international level there were tensions over who should speak for the labour movement, which trade-related issues should be prioritised, and whether to take a social partnership or more conflictual approach to the WTO. To varying extents these issues were reflected at the national level. It was also difficult to build a unified position and cross-border solidarity in relation to the GATS between unions in countries with different priorities and trade interests.

The effectiveness of the union movements' affiliate and delegate structures is another important component of MOC. As representational organisations of national unions, PSI and EI faced considerable limitations to their decision-making and organisational power in relation to mobilising a coordinated campaign against the GATS. While a global union federation may act as the official 'voice' for its affiliated unions and their members at the international level, it is the affiliated national unions who direct the policy and actions of the GUFs, and supply the majority of their resources. The main role of the GUFs is to defend and support their affiliated unions through solidarity and organisational work, which may include financial assistance or coordination of actions against employers or governments, to provide information and research and capacity building, to engage in campaigns and create public awareness, and to represent affiliate's interests with international organisations and multinational enterprises (MNCs) (see Croucher and Cotton 2009 for more on the role and function of the GUFs). On the whole, national affiliates are reluctant to give more organisational power or resources to the GUFs and sometimes see the GUFS as acting over their heads in relation to international issues, or being too removed from the issues affecting national unions and their members. The GUFs also have little direct 
contact to members and must rely on national union leaders to distribute information. This can lead to communication problems, with information not being passed on to local unions or members. This problem is exacerbated where national unions lack effective delegate structures.

Having sufficient specialist knowledge and expertise has been identified as another key MOC factor. However, in most cases, international union organisations, like PSI and EI, have relatively small staffs that are responsible for multiple issues, including trade (McGuire and Scherrer et al. 2010). The representational nature of the GUFs also means that a large portion of their financial resources and organisational capacity is dedicated to constitutional requirements and responding to specific solidarity calls from affiliates (Stevis and Boswell 2008: Ch.3). PSI and EI were no exception, with only one or two key people responsible for trade, in addition to a wide range of other international issues. Also, trade (including trade in services) was a relatively new area for public services and education unions and their federations, and one in which they initially lacked expertise. This meant that both PSI and EI had only limited resources (time, staff, expertise and money), which could be dedicated to mobilising wide-spread resistance against the GATS. In addition, the complexity of international trade processes and the issues related to the GATS made it difficult to engage affiliates in a policy issue that often appeared far removed from national union priorities and members' workplace concerns.

All of these factors restricted PSI and EI's mobilisation and organisational capacity (MOC) and their ability to develop a more 'global' and unified movement against the GATS.

As a result of the relatively closed POS and the limitations to their MOC at the international level, PSI and EI couldn't draw on institutional power to influence the GATS negotiations and they had limited capacity to exercise associational or structural power. Nonetheless, as the following description shows, they were able to find opportunities, resources and sources of power to mobilise against the GATS.

\section{MOBILISING AGAINST THE GATS - INTERNATIONAL LEVEL}

To overcome these limitations and achieve their policy goal of keeping education and other public services out of GATS, PSI and EI adopted a dual approach of lobbying, awareness raising and coalition-building at the international level, while at the same time projecting their claims down to the national level by encouraging national unions to undertake their own lobbying and awareness raising campaigns.

They lobbied the WTO Secretariat, the OECD and UNESCO, as well as WTO member states and national trade delegates located in Geneva. They formed coalitions with Geneva-based $\mathrm{NGOs}^{8}$ and worked closely with Our World is Not for Sale (OWINFS), which was the major transnational advocacy coalition opposing the GATS (as defined by Keck and Sikkink, 1998). They drew on expertise from informed affiliates and NGOs to bolster their knowledge and strategic framing capabilities, conducted a public awareness raising campaign, made links with local governments and mobilised key affiliates to put pressure on the negotiation position of national governments.

Active framing processes played a crucial role in the mobilisation process, by building both internal and external consensus about the threat presented by the GATS and the need to take action against it. Framing processes were used to identify the GATS as a shared problem and identify targets for blame and protest, to challenge existing claims and propose solutions to the problem, and to persuade unions and other groups of the necessity for taking action. These 
framing processes were deployed at three levels: 1) internally, to generate a sense of shared threat and purpose within internal union structures (i.e. within GUFs and affiliates); 2) between unions and their constituents (i.e. union members and their family and contacts) to educate them about the relevance of the issue to them and encourage them to support the campaign; and, 3) externally, to influence governments, institutional actors, wider interest groups with an interest in public services and education, media and the general public.

The following section provides an overview of the main framing and mobilising processes and strategies used in the campaign. Unfortunately, it is not possible within the restraints of this article to include specific details or illustrative quotes (for an in-depth account of the mobilisation and framing processes see McGuire 2013: Ch. 5).

PSI and EI framed the GATS as a series of inter-linked problems but predominantly as a threat to the policy and regulatory power of national governments (i.e. national sovereignty) and to the equitable delivery of public and essential services (PSI and EI, 1999a and b). They raised fears that GATS rules would override government decision making, that the liberalisation of services through the GATS would escalate the deregulation and privatisation of public and essential services, and that existing commercialisation and privatisation would make these services more vulnerable to being incorporated into the GATS. They also raised fears that the GATS would exacerbate existing problems such as skill drain and use of foreign workers. Frames were adjusted as the campaign progressed and new issues or opportunities in the negotiation process emerged.

The problem was blamed on the interests pushing the GATS i.e. greedy corporate interests, powerful services-exporting national governments, and the system of 'profit-driven' globalisation and trade liberalisation itself. The WTO (and its negotiation processes) was framed as intransparent, undemocratic and unfair, especially to developing countries.

To fix the problem unions proposed that public and essential services should be excluded from the scope of the GATS, that a moratorium on services negotiations be held until its potential impacts could be assessed, that the GATS should be changed to protect the regulatory power of national governments and that there should be a fairer process of free trade.

The main call to action was for affiliates to conduct a national lobbying and awareness raising campaign designed to persuade national governments not to make further commitments of services to the GATS and not to demand commitments from other countries. The overarching message was that the GATS could have serious unforeseen consequences for public services and for domestic policymaking, and that it must therefore be constrained or stopped before it is too late. As proof that union and civil society action can influence and even stop negotiations, PSI and EI pointed to civil society success in defeating the proposed Multilateral Agreement on Investment (MAI) and a new trade round in Seattle in 1999 (PSI and EI, 2006).

The lack of official access to the multilateral trade negotiation process and limits to resources and expertise were countered by a number of factors. The divisive nature of the GATS negotiations, especially the conflict between developed and developing countries (Kelsey 2008: Ch. 3), provided opportunities to highlight the unfairness of the WTO and GATS negotiations, to drive wedges between negotiators, and to win allies amongst WTO member states. WTO Ministerial meetings and key junctures in the GATS negotiations provided situational opportunities (SO) for escalating lobbying and campaigning activity. International meetings also provided valuable opportunities for activists to exchange ideas, frames and strategies, and build 
common positions. Importantly, the existence of a broader civil society movement against the GATS provided existing allies, resources, expertise and protest frames.

\section{POS, MOC AND POWER - NATIONAL LEVEL}

At the national level the research found significant differences between the country cases in terms of the political opportunity structure, the mobilising and organisational capacity of unions in relation to trade, and also in the extent to which the GATS was picked up by unions as an important policy issue.

As at the international level, unions in Australia had quite limited formal and informal access to the trade policy and political system, due to institutional limitations and exclusion by a hostile anti-union government (i.e. relatively closed POS), and restrictions to their MOC. This included limited expertise and resources dedicated to trade, lack of effective delegate structures and restrictions to political mobilisation on issues outside the workplace. In South Africa, on the other hand, unions had good access to the trade policy and political system, through their participation in tripartite institutions and strong formal and informal connections to the labourfriendly government (i.e. relatively open POS), and relatively strong MOC, including strong political mobilisation capacity, considerable trade expertise and a high level of resources dedicated to trade.

\section{UNION MOBILISATION AGAINST THE GATS - AUSTRALIA}

Despite the relatively closed POS and limited union MOC, there was a sustained union and civil society campaign against GATS in Australia, which included action by national unions affiliated to PSI and EI. However, as unions and civil society in Australia are to a large extent locked out of the trade policy process, unions were unable to use formal strategies of access such as social dialogue (institutional power). Nor, were they able to employ 'insider strategies', which require friendly relationships with the ruling political party (associational power), as there was a union-hostile political party in government.

Nonetheless, unions were able to utilise their institutional power as citizens to take advantage of some limited formal access to the trade policy process through the parliamentary system. In Australia, all decisions about the negotiation of treaties, including objectives, negotiating positions, and the final decision to sign and ratify an agreement are made by the executive arm of Government rather than by Parliament (DFAT 2008: 3). However, since 1996 a special joint parliamentary committee has been established, with the power to review trade agreements, accept public submissions and hold public meetings (ibid). Unions and civil society actors used this small opening to write submissions, attend public meetings, and create further opportunities for consultation, awareness raising and leverage.

As at the international level, unions relied heavily on both discursive strategies such as lobbying, awareness raising and strategic framing, and coalition building. They lobbied members of the opposition party and independent members of parliament to raise their concerns about the GATS and the WTO in parliament and push for public hearings on trade agreements. This gave them the opportunity to make submissions and provide evidence at public hearings. They successfully used these hearings to 'scandalise' in the media the lack of transparency and democratic decision making in the trade negotiating process and raise public concern about the 
potential threat of both the GATS and a major bilateral trade agreement under negotiation with the U.S.

Unions and civil society activists had a degree of mobilisation and organisational readiness built up by previous campaigning against the proposed Multilateral Agreement on Investment (MAI) some years earlier, including an existing stable union and civil society coalition for fair trade, the Australian Fair Trade and Investment Network (AFTINET). This coalition played a major role in creating awareness and mobilising support both within and outside the union movement, which, to some extent, compensated for the limited communication and delegate structures within unions (Peetz 1998), and the difficulty of engaging members in a complex and seemingly 'distant' issue. On the other side, unions provided the bulk of financial support for this coalition.

The GATS negotiations were strongly linked to the existing trend of privatisation of public services in Australia (Ranald 2001). As at the international level, GATS was framed as a threat to public and essential services (AFTINET 2009). Activists used two forms of 'scale shift' as identified by Tarrow (2005) to strengthen domestic claims and mobilisation. They reframed on-going domestic privatisation as endangering public services by exposing them to further liberalisation through the GATS (global framing). And, they framed the enforceable WTO and GATS rules and regulations as an encroachment of external power into the domestic realm (internalisation). This reflects the high level of concern in Australia about on-going deregulation and privatisation of public services and the government's aggressive interests in exporting services, especially higher education services. Activists also emphasised the 'democracy deficit' inherent in the trade negotiation and agreement making process, both nationally and in the WTO.

Here, as in the global campaign, situational opportunities in the trade policy process played a key role. Lobbying, awareness raising and campaign activity tended to mirror the GATS negotiation deadlines and meetings, and played on divisions that emerged within the negotiations, mainly between developed and developing countries. One can observe a similar spiral of 'opportunity and threat', with key WTO events and junctures in services negotiations providing situational opportunities for escalating lobbying and campaigning activity and for building common positions.

The lack of access to the trade policy process was partly offset by the highly charged political atmosphere in Australia, where international trade was already a public issue, and where the government of the day was vulnerable to accusations about the on-going democracy deficit in trade policy and the agreement making process, especially as they had made election promises to address this problem (Capling and Nossal, 2003). To some extent this created a 'receptive' discursive environment.

\section{MOBILISATION AGAINST THE GATS - SOUTH AFRICA}

In South Africa there was no identifiable campaign against the GATS, despite the apparent existence of all the factors necessary for such a campaign to emerge, including: growing concerns about the intrusion of international institutions into the domestic regime; the existence of government driven commoditisation and privatisation of social services; the awareness of GATS-related issues, both within the union movement and civil society; and, despite organised labour having both the opportunity and capacity to intervene in the trade policy process. 
South African unions have a long tradition of political engagement, driven by labour's enduring interest in liberation and national development (Pillay 2008). As a result of earlier struggles, unions have formal input into the trade policy making and negotiating positions through a tripartite institution, the National Economic Development and Labour Council (NEDLAC) (Finnemore 2002: 115). In addition, the main union federation, COSATU, also has formal and informal channels of access to ministers and key decision makers through its alliance with the governing ANC (Adler and Webster 2000) and contact with former unionists who have become members of parliament and subsequently government ministers (IUR 2009: 19).

The main reasons for the lack of a union campaign against the GATS in South Africa seem to have been: the lack of resonance that the GATS-related issues (as defined at the international level) had with the domestic policy concerns of the main union federation, COSATU; the strategic decisions of union leaders; the existence of alternative channels for influencing trade policy, and COSATU's reluctance to work closely with potential social movement allies.

In South Africa, the union movement's main trade-related priority was on improving jobs and national development through manufacturing related exports, rather than services. In addition, key members of the COSATU leadership simply didn't see the GATS as a threat to the provision of public services and education. COSATU did make some early political demands in relation to the GATS through the Alliance. However, once union leaders accepted government assurances that they wouldn't make further commitments of essential services in GATS, this reduced the level of threat and closed opportunities to mobilise grass-roots action around this issue. In addition, COSATU preferred to set its own agenda and was reluctant to work with potential social movement allies that were critical towards the ANC. While COSATU did mobilise considerable domestic contention against the privatisation and commodification of essential services, especially water, this was regarded as a problem of domestic regulation and not connected to external pressures associated with the GATS.

In other words, unlike the Australian case, unions in South Africa did not co-opt global themes to fight domestic battles. They did not frame the domestic issue of privatisation and deregulation of services in global terms, nor did they perceive these policies as related to the external threat of the GATS.

This cannot be simply attributed to a lack of international focus or capacity. As a subsequent campaign against the Non-Agriculture Market Access (NAMA) negotiations shows (Busser 2009), COSATU did have sufficient international focus and capacity to campaign against an international trade agreement and to use global framing to support a domestic issue (threat to jobs in manufacturing), when that issue was considered of sufficient relevance. The lack of a campaign against the GATS seems mainly related to leadership decision making about which issue to prioritise, and the nature of the political opportunity structure. As a result of its institutionalised access to the political and policy process (institutional power) COSATU was able to use 'insider' strategies to put the union movement's position on the GATS forward. It had sufficient MOC and associative power to undertake a campaign but as government appeared responsive to their demands, key union leaders considered this uneccesary. 


\section{IMPACT OF UNION CONTENTION AGAINST THE GATS}

The outcomes of union contention against the GATS should be assessed in terms of their external and internal impact rather than on the success or failure of achieving union policy goals. This enables the capture of both intended and unintended consequences of union action (Guigni 1995). The research shows that despite being faced with a relatively closed political system and having limited mobilisation capacity and resources to dedicate to trade, unions at both the international level and the national level, in Australia, were able to have an impact on the GATS negotiations.

Probably the most important external impact of union action was its sensitising effect. Along with other civil society actors, unions successfully defined the GATS as a shared social problem and raised widespread awareness (within unions and international institutions, and with politicians, parliamentarians, the media, and the broader public) of its potential threat to the delivery of public and essential services and domestic regulation. This increased the level of public fear and uncertainty and had a cautionary effect on governments, making them more reluctant to make services commitments. There were substantially fewer services commitments during the period studied, than had been initially expected (by unions and by the WTO and pro-service countries).

To a limited extent unions were also able to have an impact on the political opportunity structure itself; not so much on the institutional aspects but on the negotiating environment. The combined civil society and union campaign against the GATS helped delegitimise the WTO (and the GATS) negotiating processes as unfair and undemocratic, thus forcing the WTO on the defensive and slowing down negotiations. In addition, unions achieved recognition, if not formal acknowledgement, that they are significant actors in the international trade negotiation and policy process. They also established important informal avenues of access by developing relationships and alliances with key developing country trade negotiators and with some 'sympathetic' WTO officials.

In addition, the union struggles against the GATS built substantial internal union capacity within global union organisations and key national unions.

- It increased the level of knowledge and expertise about trade policy and negotiations, its possible impact on members and where to intervene.

- Unions honed their framing capabilities and adopted new strategies of contention, which could potentially be adapted to other campaigns.

- It built bridges with NGOs and social movement networks. This reduced levels of existing distrust between unions and NGOs (especially at the international level) and resulted in longstanding alliances.

- It built up a network of informed trade activists within the union movement. However, this layer of expertise and activism remains relatively thin and confined to key individuals within the union movement and may not be sustainable in the long term.

\section{Discussion of Key Findings}

The application of the theoretical framework developed for this research reveals a number of key findings, which have relevance for social movement theory and labour research. 
First, intergovernmental negotiations and policy processes can themselves create a multilevel opportunity structure, which, in turn, facilitates the development of innovative multilevel strategies. The multilateral nature of the international trade negotiation process forced unions to operate at both levels in trying to influence the GATS negotiations. This encouraged the development of innovative multilevel strategies.

Second, faced with a closed political/institutional system at the international level, international union organisations used the national level to leverage their demands, in a type of 'reverse' boomerang effect (Keck and Sikkink 1998). ${ }^{9}$ At the same time, union activists at the national level (in Australia) utilised two processes of scale shift, 'global framing' and 'internalisation' (as described by Tarrow, 2005), to strengthen their demands and escalate existing mobilisation against the privatisation and deregulation of public services. This supports growing evidence that social movements and other political groups are able to actively transform opportunity structures at the international level and use international institutions and issues to alter domestic opportunity structure (Sikkink 2005 and Tarrow 2005).

Third, Situational Opportunities (SO) can provide openings for action even in closed political systems. Even where unions faced a relatively closed POS, key junctures in intergovernmental policy and negotiation processes (e.g. international meetings, agenda setting, deadlines) provided 'windows of opportunity' for articulating grievances, forming alliances and mobilisation. The trade negotiation process created an 'opportunity/threat spiral' (Tarrow 2005, Karapin 2011) in which key points in negotiations and the actions of authorities or elites created new grievances that triggered further protest and mobilisation by challenger groups.

Fourth, it demonstrates the importance of expertise and strategic framing capabilities for mobilisation. The multilevel strategies used by the GUFs and national unions relied heavily on them developing sufficient expertise and knowledge to frame the GATS in a way that: linked it to existing international and domestic concerns; that co-opted global symbols to strengthen domestic demands; that extended the problem and thus the mobilisation potential beyond the workplace; that amplified the threat into an attack on national sovereignty; and, that contested the claims made by the WTO and trade in services supporters.

Fifth, unions are able to shift domains and adopt strategies to leverage 'weakened' power. Unions in this study drew on coalition building and discursive power to compensate for the lack of institutional power and to leverage weakened associational power. Where they lacked institutional and political access (and thus power) in the labour rights domain, unions in Australia shifted to the citizenship domain where they could draw on their legislative and symbolic power as citizens. This supports observations by Gentile and Tarrow (2009) that unions are able to successfully shift the locus of activism where traditional sources of power are weakened or unavailable.

And finally, opportunity and capacity shape mobilisation but not as directly as expected. A limited or relatively closed POS and limited MOC does not prevent mobilisation on a particular issue. On the other hand, an open political system and good mobilisation and organisational capacity does not necessarily lead to union mobilisation. The national case studies looked at in this research seems to indicate that a lack of POS could actually provoke mobilisation due to the lack of other possibilities to access the political process, while the existence of good avenues of institutional and political access could lead unions to utilise more 'insider' strategies. The role of key union leaders in assessing the degree of perceived threat and 
relevance of an international issue to the domestic concerns of members also appears important. The role of leadership decision-making in union mobilisation needs further investigation.

\section{Robustness of Framework and Potential Future Application}

As shown above, this research demonstrates the effectiveness of social movement theory based concepts of political opportunity structure (POS), mobilising and organisational capacity (MOC), and framing, to analyse and explain factors impacting on labour mobilisation at the international and national levels.

The analytical framework developed from these concepts provided valuable insights into the opportunities for and constraints to organised labour's capacity to influence the GATS negotiations. Many of these findings have broader implications for social movement theory and labour research.

The development of a four-fold labour power dimension is particularly important for labour research as it makes explicit the sources of power that unions are able to draw on to exert influence and how these sources of power are affected by the external context and unions' internal capacity. It also addresses the need in SMT for better conceptual tools to capture the sources of power available to movements, and how they impact on POS, mobilisation of resources and choice of strategies.

I argue that the analytical framework developed for this research has potential to strengthen the theory and practice of union organizing and strategic campaigning. Existing theory and practice does not sufficiently consider the broader political and social context in which campaigns take place. In addition, insufficient attention is paid to assessing unions' own resources and capabilities and the discursive processes through which they challenge hegemonic policies and practices, build consensus for change, and mobilise collective action in support of that change. The broader question of the source and strength of union power, particularly in relation to the issue and field being targeted, is also not sufficiently analysed. All of the above factors are important, as they impact on the strategic decisions made in relation to planning and implementing a successful campaign, including the appropriate choice of strategies and coalition partners. The framework developed for this research provides conceptual tools that can help address that gap.

Nonetheless, there are some areas of the theoretical framework that need to be strengthened as part of this process. The concept of mobilisation and organisational capacity still lacks analytical clarity. ${ }^{10}$ In particular, the special nature of unions as representative bodies of workers needs further conceptualisation, including the role played by institutional actors (e.g. union leaders) and systems (e.g. management, decision making structures, bureaucracy) in resource mobilisation. This point could be addressed by a selective borrowing of concepts from the field of organisational studies (as suggested by Davis, McAdam, Scott and Zald 2005). It would also help to make a clearer distinction between having resources and the 'strategic capabilities' needed to utilise them effectively, as suggested by Lévesque and Murray (2010).

Further case studies are clearly needed to test the effectiveness of the framework for analysing and enriching union organising strategies and campaigns and to bring more clarity to the concepts and indicators. 


\section{NOTES}

1. See Voss and Sherman (2000), Hyman (2001), Clawson (2003), for South Africa, Pillay (2008) and Kenny and Webster (1999), for Australia, Peetz (1998).

2. Polanyi (1944) argued that the negative impact of the unregulated progress of market forces, especially the commodification of all aspects of life, would eventually lead to the development of a counter movement.

3. The International Trade Union Confederation (ITUC) and some other GUFs were also engaged in protests against the GATS but PSI and EI were by far the most active.

4. The approach is similar to the political process model developed by McAdam (1982) and later used by Ayers (1998).

5. Mobilisation and Organisational Capacity (MOC) is my own compilation and attempt to bring some clarity to resource mobilisation.

6. Interview schedule available on request.

7. Except where referenced this empirical section draws on expert interviews and campaign websites and material.

8. This included the Institute for Agriculture and Trade Policy (IATP), Oxfam, Friends of the Earth, 3D, the Ecumenical Alliance for the World Council of Churches, Focus on the Global South, and the Third World Network (TWN), and some other GUFs.

9. A boomerang effect is where activists facing a closed domestic decision making level appeal to the international level (foreign government/international institution), to put pressure on their national government.

10. The lack of clarity of resources and resource mobilisation has been recognised by other SMT theorists (e.g. McAdam 1996, Rucht 1996).

\section{REFERENCES}

Adler, G. and Webster, E. (eds) (2000) Trade Unions and Democratisation, 1985-1997. London: Macmillan.

AFTINET (2009) Australian Fair Trade and Investment Network. Available at: http://www.aftinet.org.au/index.html [Accessed 18 March 2009]. 
Ayers, J. (1998) Defying Conventional Wisdom: Political Movements and Popular Contention Against North American Free Trade. Toronto: University Toronto Press.

Benford, R.D. and Snow, D.A. (2000) 'Framing Processes and Social Movements: An Overview and Assessment', Annual Review of Sociology 26: 611-39.

Busser, E. (2009) 'The NAMA 11 Trade Union Group: Overview and Achievements'. Geneva: ITUC, Internal paper.

Capling, A. and Nossal, K.R. (2003) 'Parliament and the Democratization of Foreign Policy: The Case of Australia's Joint Standing Committee on Treaties', Canadian Journal of Political Science 36(4): 835-855.

Chun, J.J. (2009) Organising at the Margins: The Symbolic Politics of Labour in South Korea and the United States. Ithica: Cornell University Press.

Clawson, D. (2003) The Next Upsurge: Labor and the New Social Movements. Ithaca: Cornell University Press.

Croucher, R. and Cotton, E. (2009) Global Unions Global Business. Global Union Federations and International Business. London: Middlesex University Press.

Davis, G.F., McAdam, D., Scott, R.W. and Zald, M.N. (eds) (2005) Social Movements and Organization Theory. New York: Cambridge University Press.

Department of Foreign Affairs and Trade (DFAT) (2008) 'Australia and International Treaty Making Information Av'. Available at: http://www.austlii.edu.au/au/other/dfat/reports/infokit.html [Accessed 21 August 2008].

Dörre, K., Holst, H. and Nachtwey, O. (2009) 'Organising - A Strategic Option for Trade Union Renewal?', International Journal of Action Research 5(1): 33-67.

Evans, P. (2005) 'Counterhegemonic Globalization: Transnational Social Movements in the Contemporary Global Political Economy', in T. Janoski, R. Alford, A.M. Hicks and M.A. Schwartz (eds), The Handbook of Political Sociology. States, Civil Societies, and Globalization (pp. 655-670). New York: Cambridge University Press.

Fairbrother, P. and Hammer, N. (2005) 'Global Unions. Past Efforts and Future Prospects', Relations Industrielles/Industrial Relations 60(3): 405-431.

Finnemore, M. (2002) Introduction to Labour Relations in South Africa, (8th Edition). Durban: LexisNexis Butterworths.

Frege, C., Heery, E. and Turner, L. (2004) 'The New Solidarity? Trade Union CoalitionBuilding in Five Countries', in C. Frege J. and Kelly (eds), Varieties of Unionism: 
Strategies for Union Revitalisation in a Globalising Economy (pp. 137-158). New York: Oxford University Press.

Frundt, H.J. (2005) 'Movement Theory and International Labor Solidarity', Labour Studies Journal 30(2): 19-40.

Gentile, A. and Tarrow, S. (2009) 'Charles Tilly, Globalization, and Labor's Citizen Rights', European Political Science Review 1(3): 465-493.

Gerhards, J. (1995) 'Framing Dimensions and Framing Strategies: Contrasting Ideal- and Realtype Frames', Social Science Information 34(2): 225 -248.

Giugni, M. G. (1995) 'Outcomes of New Social Movements, in H. Kriesi, R. Koopmans, J.W. Duyvendak and M.G. Giugni (eds), New Social Movements in Western Europe: A Comparative Analysis (pp. 207-237). London: UCL Press.

Global Unions Group, WTC and ETUC (2005) 'Trade Union Statement on the Agenda for the 6th Ministerial Conference of the World Trade Organisation (WTO)'. Hong Kong, 1318 December 2005. Brussels: ICFTU.

Hall, D. (2001) Globalisation, Privatisation and Healthcare - A Preliminary Report. Greenwich: Public Services International Research Unit (PSIRU), University of Greenwich.

Hartmann, E. and Scherrer, C. (2003) Negotiations on Trade in Services. The Position of the Trade Unions on GATS. Bonn: FES.

Hajer, M.A. (1995) The Politics of Environmental Discourse. Ecological Modernization and the Policy Process. London: Clarendon Press.

Hajer, M.A. (2006) 'Doing Discourse Analysis: Coalitions, Practices, Meaning', in M. van den Brink and T. Metze (eds), Words Matter in Policy and Planning Discourse Theory and Method in the Social Sciences (pp. 65-74). Utrecht: Netherlands Graduate School of Urban and Regional Research.

Hyman, R. (2001) Understanding European Trade Unionism: Between Market, Class and Society. London: Sage

International Union Rights (IUR) (2009) 'Special Focus: South Africa', International Union Rights 16(4): 12-24.

Jawara, F. and Kwa, A. (2003) Behind the Scenes at the WTO: The Real World of International Trade Negotiations. London/Bangkok: Zed Books and Focus on the Global South.

Karapin, R. (2011) 'Opportunity/Threat Spirals in the U.S. Women's Suffrage and German Anti-immigration Movements', Mobilisation 16(1): 65-80. 
Keck, M., and Sikkink, K. (1998) Activists Beyond Borders: Advocacy Networks in International Politics. Ithaca: Cornell University Press.

Kelsey, J. (2008) Serving Whose Interests? The Political Economy of Trade in Services Agreements. New York: Routledge.

Kenny, B. and Webster, E. (1998) 'Eroding the Core: Flexibility and the Re-segmentation of the South African Labour Market', Critical Sociology 24(3): 216-243.

Krajewski, M. (2001) 'Public Services and the Scope of The General Agreement on Trade in Services.' Washington: Centre for International Environmental Law (CIEL).

Lévesque, C. and Murray, G. (2010) 'Understanding Union Power: Resources and Capabilities for Renewing Union Capacity', Transfer: European Review of Labour and Research 2010(16): 333-350.

McAdam, D. (1982) Political Process and the Development of Mass Insurgency, 1930-1970. Chicago: University of Chicago Press.

McAdam, D. (1996) 'The Framing Function of Movement Tactics. Strategic Dramaturgy in the American Civil Rights Movement', in D. McAdam, J. McCarthy and M.N. Zald (eds), Comparative Perspectives on Social Movements. Opportunities, Mobilizing Structures and Framing (pp. 338-340). Cambridge: Cambridge University Press.

McAdam, D., McCarthy, J. and Zald, M.N. (ed) (1996) Comparative Perspectives on Social Movements. Opportunities, Mobilizing Structures and Framing. Cambridge: Cambridge University Press.

McCarthy, J.D., and Zald, M.N. (1997) 'Resource Mobilization and Social Movements: A Partial Theory', in S.M. Buechler and F.K. Cylke (eds), Social Movements: Perspectives and Issues (pp. 149-171). California: Mayfield Publishing Company.

McCarthy, J.D., Smith, J. and Zald, M.N. (1996) 'Accessing Public, Media, Electoral, and Governmental Agendas', in D. McAdam, J. McCarthy and M.N. Zald, Meyer (eds), Comparative Perspectives on Social Movements. Opportunities, Mobilizing Structures and Framing (pp. 291-311). Cambridge: Cambridge University Press.

McGuire, D. (2013) Re-Framing Trade: Union Mobilisation Against the General Agreement on Trade in Services (GATS). München, Mering: Rainer Hampp.

McGuire, D. and Scherrer, C. et al. (2010) 'Developing a Labour Voice in Trade Policy at the National Level’. GLU Working Paper No. 8. Berlin: Global Labour University.

Meyer, D. (2004) 'Protest and Political Opportunities', Annual Review of Sociology 30: 125-145. 
Munck, R. (2002) Globalisation and Labour: The New 'Great Transformation'. London: Zed Books.

Peetz, D. (1998) Unions in a Contrary World. The Future of the Australian Trade Union Movement. Cambridge: Cambridge University Press.

Pillay, D. (2008) 'Globalisation and the Informalisation of Labour: The Case of South Africa', in A. Bieler, I. Lindberg and D. Pillay (eds), Labour and the Challenges of Globalisation (pp. 45-64). Scotville: University of Kwa-Zulu Natal.

Polanyi, K. (1944) The Great Transformation: The Political and Economic Origins of Our Time. Boston: Beacon Press.

Public Services International and Educational International (PSI and EI) (1999a) The WTO and the Millennium Round: What is at Stake for Public Education? Common Concerns for Workers in Education and the Public Sector. Ferney-Voltaire/Brussels: PSI and EI.

PSI/EI (1999b) The WTO and the Millennium Round: What is at Stake for Public Health? Common Concerns for Workers in Education and the Public Sector. FerneyVoltaire/Brussels: PSI and EI.

PSI and EI (2006) Stop the World? No. Shape It! Ferney-Voltaire/Brussels: PSI and EI.

Ranald, P. (2001) 'The WTO Trade in Services Agreement: Privatisation by Stealth?', speech at the Public Meeting on Privatisation, Sydney, 21 May 2001. Available at: http://aftinet.org.au/papers/ranald1.html [Accessed 21 August 2008].

Robinson, I. (1994) 'NAFTA, Social Unionism, and Labour Movement Power in Canada and the United States', Industrial Relations 49(4): 657-695.

Rucht, D. (1996) 'The Impact of National Contexts on Social Movement Structures: A CrossMovement and Cross-National Comparison', in D. McAdam, J. McCarthy and M.N. Zald (eds), Comparative Perspectives on Social Movements. Opportunities, Mobilizing Structures and Framing (pp. 185-204). Cambridge: Cambridge University Press.

Scherrer, C. (2002) 'GATS Negotiation Round in the Education Sector', GATS: Trading Development?'. Warwick UK: Centre for the Study of Globalisation and Regionalisation, University of Warwick.

Sikkink, K. (2005) 'Patterns of Dynamic Multilevel Governance and the Insider-Outsider Coalition', in D. della Porta and S. Tarrow (eds), Transnational Protest and Global Activism. Lahnham, MD: Rowman and Littlefield.

Silver, B. (2003) Forces of Labor: Workers' Movements and Globalisation Since 1870. Cambridge: Cambridge University Press. 
Stevis, D. and Boswell, T. (2008) Globalization and Labor: Democratizing Global Governance. Lanham, MA: Rowman \& Littlefield.

Sutton, R. (1999) 'The Policy Process: An Overview'. ODI Working Paper 118. London: Overseas Development Institute.

Tarrow, S. (1998) Power in Movement (2nd edition). New York: Cambridge University Press.

Tarrow, S. (2005) The New Transnational Activism. New York: Cambridge University Press.

Tattersall, A. (2010) Power in Coalition. Strategies for Strong Unions and Social Change. Ithaca: Cornell University Press.

Tilly, C. (1978) From Mobilization to Revolution. Indianapolis: Addison-Wesley Publishing Company.

Turner, L. (2006) 'Globalization and the Logic of Participation: Unions and the Politics of Coalition Building', Journal of Industrial Relations 48(1): 83-97.

Voss, K. and Sherman, R. (2000) 'Breaking the Iron Law of Oligarchy: Union Revitalization in the American Labor Movement', The American Journal of Sociology 106(2): 303-349

Webster, E. and Adler, G. (1999) 'Toward a Class Compromise in South Africa's "Double Transition": Bargained Liberalization and the Consolidation of Democracy', Politics and Society 27(3): 347-385.

Webster, E., Lambert, R. and Bezuidenhout, A. (2008) Grounding Globalization: Labour in the Age of Insecurity. London: Blackwell.

WTO

(2010)

'Understanding

the WTO'.

Available

at: http://www.wto.org/english/thewto_e/whatis_e/tif_e/fact1_e.htm. [Accessed 21 July 2010].

\section{BIOGRAPHICAL NOTE}

DONNA MCGUIRE holds an M.A. and doctoral degree in political science from the University of Kassel (Germany) and she is a Post-Doc Fellow member of the Global Social Policies and Governance (GSPG) graduate college. Her research focuses on union renewal and building union power in the global political economy. She has worked as a journalist and communications specialist in the labour movement in Australia. She is active in union renewal discussions at the international level and currently works as an independent labour researcher. [email: dmc.media@yahoo.com.au] 